\title{
Primeiro relato de oídio em Sesbania punicea Benth (Cav.) no Brasil
}

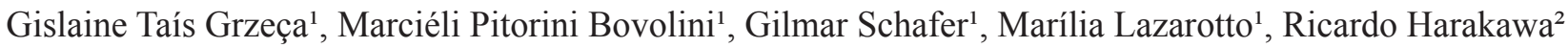

${ }^{1}$ Universidade Federal do Rio Grande do Sul, Faculdade de Agronomia, Departamento de Horticultura e Silvicultura. Porto Alegre, RS - Brasil. ${ }^{2}$ Instituto Biológico de São Paulo, Avenida Conselheiro Rodrigues Alves, no 1.252, CEP 04014-002 São Paulo, SP, Brazil. Autor para correspondência: Gislaine Taís Grzeça (gis_tais@hotmail.com) Data de chegada: 27/03/2017. Aceito para publicação em: 10/11/2017.

$10.1590 / 0100-5405 / 177610$
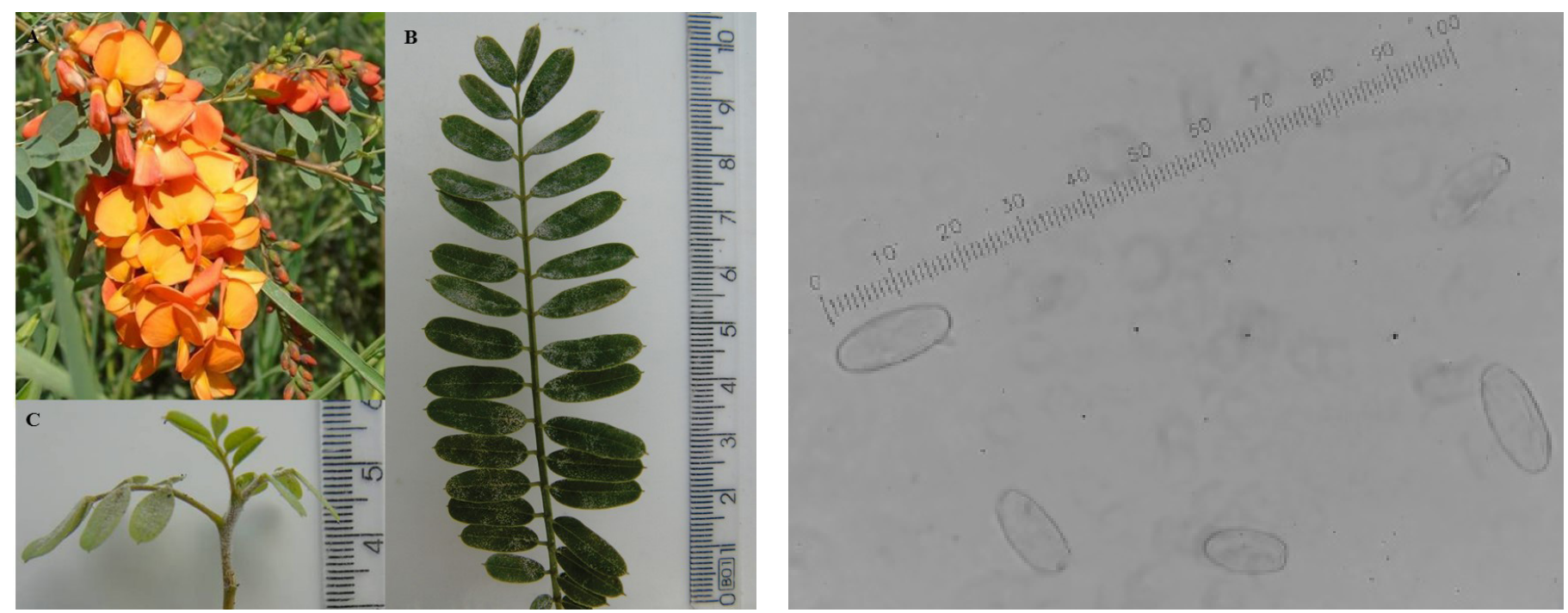

Figura 1. Aspectos de Sesbania punicea. A. Inflorescência. B. Sintomas de oídio em folíolos. C. Sintomas de oídio no caule e folhas de muda. D. Conídios de Erysiphe trifoliorum (régua micrométrica - aumento de 400 x).

Sesbania punicea Benth. (Cav.) (Família Fabaceae) é uma planta nativa do Bioma Pampa, muito encontrada no sul do Brasil em áreas abertas e degradadas. Conhecida popularmente por fedegoso-da-praia, é uma planta caducifólia que pode alcançar de 2 a $4 \mathrm{~m}$ de altura e apresenta potencial ornamental, destacado por suas inflorescências vermelho-alaranjadas (Figura 1A), reunidas em racemos pendentes de acordo com Stumpf et al. (Cores e Formas no Bioma Pampa: plantas ornamentais nativas. 2009. 276 p.).

Em coletas à campo no município de Alegrete - RS, foram observados sintomas típicos de oídio em plantas adultas, com intensa esporulação pulverulenta esbranquiçada, no verão de 2015. A partir da produção de mudas por sementes, em cultivo protegido, os sintomas se manifestaram igualmente e de forma intensa, entretanto, até o presente momento, não há relatos do patógeno para a espécie no Brasil. Em janeiro de 2016, foi realizado teste para confirmação da patogenicidade, em estufa com telado nas laterais pertencente à Faculdade de Agronomia - Universidade Federal do Rio Grande do Sul. Para a inoculação, foram utilizadas 20 mudas, divididas em quatro repetições de cinco plantas em delineamento inteiramente casualizado, sem controle de temperatura e umidade. A inoculação foi realizada através de raspagem com pincel de cerdas macias nos folíolos de mudas naturalmente infectadas e transferindo o inóculo para mudas sadias. As plantas apresentaram sintomas de esporulação pulverulenta esbranquiçada, ao final de 30 dias, principalmente em folíolos do terço inferior das plantas (Figuras 1B e 1C). A identificação foi realizada por métodos moleculares iniciando com a coleta de conídios por bomba à vácuo, os quais foram enviados para sequenciamento da região Internal Transcribed Spacer e, realizado no Instituto Biológico de São Paulo, posteriormente, realizou-se o alinhamento da sequência obtida com as disponíveis no GenBank. Através da análise molecular, a sequência se aproximou da espécie Erysiphe trifoliorum (Wallr.) U. Braun com $100 \%$ de identidade pelo método BLAST. Os conídios apresentam as seguintes dimensões: comprimento: $35 \times 45 \mu \mathrm{m}$ (média $=40 \mu \mathrm{m})$; largura 16 × $20 \mu \mathrm{m}$ (média $=18 \mu \mathrm{m})$.

Considerando nosso conhecimento, este é o primeiro relato de $E$. trifoliorum atacando a espécie $S$. punicea no Brasil. Na Argentina foi relatado oídio em $S$. punicea, porém o fungo que incidiu nessa planta é Erysiphe sesbaniae (Wolcan \& U. Braun), sp. nov. segundo descrição de Braun et al. (Mycotaxon, v. 112, p. 173-187, 2010).

\section{REFERÊNCIAS}

1. Braun, U.; Kruse, J.; Wolcan, S.M.; Murace, M. Three new species of the genus Erysiphe (Ascomycota, Erysiphales) on legumes and some new combinations. Mycotaxon. v. 112, p. 173-187, 2010.

2. Stumpf, E.R.T.; Barbieri, R.L.; Heiden G. (Ed.) Cores e Formas no Bioma Pampa: Plantas ornamentais nativas. Pelotas: Embrapa Clima Temperado, 2009. $276 \mathrm{p}$. 